\title{
In Vitro Analysis of Effect of Heat Used in Dental Bleaching on Human Dental Enamel
}

\author{
Gilson Blitzkow SYDNEY ${ }^{1}$ \\ Fernando Branco BARLETTA ${ }^{2}$ \\ Roberto Bittencourt SYDNEY ${ }^{3}$ \\ ${ }^{1}$ Department of Endodontics, Dental School, Federal University of Paraná, Curitiba, PR, Brazil and \\ Tuiuti's Dental School, Curitiba, PR, Brazil \\ ${ }^{2}$ Luteran University of Brazil, Canoas, $R S$, Brazil \\ ${ }^{3}$ Department of Endodontics, Federal University of Paraná, Curitiba, PR, Brazil
}

\begin{abstract}
From a cosmetic point-of-view, white teeth are important for integration of an individual into society. Thus, dental bleaching may be used to reach this objective. When analyzing several proposed techniques, it was observed that heat is frequently involved either in direct application or as a result of a chemical reaction. Taking into account the importance of preserving dental structures, the present study analyzed possible injuries to enamel when heat is used in the bleaching procedure. A colorimetric method was used and the results showed that there was no difference when heat was used. In only one case did the non-communicating tufts become communicating.
\end{abstract}

Key Words: dental bleaching, enamel tufts.

\section{INTRODUCTION}

Currently, cosmetics and esthetics are deeply connected to white teeth and this is of major importance for the relationship of people in society. Thus, dental bleaching plays an important role as an alternative therapy to reach this objective.

When using this therapy, two distinct situations must be considered: vital and non-vital teeth bleaching with the application of chemicals, heat and/or light on the tooth surface $(1,2)$.

Problems with the techniques should be taken into account because the use of acid substances on the enamel surface may cause wear and increase roughness. The use of caustic substances in contact with heat may also produce a negative effect in the structure of hard tissues (1-3).

Studying different techniques proposed for dental bleaching, it is possible to see that heat is frequently involved either in direct application or as a result of a chemical reaction.

Enamel and dentin present a thermo-dynamic reaction when heat is applied. Both tissues contract, and this process is faster in dentin than in enamel. This thermo-dynamic behavior generates stress between both structures, thus producing cracks or making pre-existing fissures become clear $(1,2,4,5)$.

Dental enamel density decreases from its surface to the area close to the dentin-enamel junction. This structure is basically composed by inorganic substances, $96 \%$ of mineral components, $4 \%$ of organic components and water. The basic structure of enamel is formed by prisms which are not visible at the dentin-enamel junction, as well as in some peripheral areas $(4,5)$.

Lamellae are basically linear fissures or cracks that can be observed under low magnification. They extend from the enamel surface in a longitudinal and radial direction and can be limited to enamel structures or even penetrate dentin (4-6).

According to Osborn and Ten Cate (4), lamella can result from a development differentiation in which a matrix slice of dental enamel did not complete its mineralization process. Another factor could occur after the development of the complete structure, but before total mineralization: enamel could be compressed and suffer fissures. In elderly people, dental enamel sometimes cracks and saliva debris invade these fissures producing this type of lamella. 
Lutz et al. (7) reported that true lamellae are inter-prismatic substances and irregular shapes of enamel prisms with low calcification, with a width of 5-86 micrometers.

According to Ten Cate (5), the tufts emerge from the dentin-enamel junction. They are hypomineralized structures in the shape of sheets or strips. The embryologic origin of these structures may be related to the forces produced by dimensional alterations during dental enamel maturation.

Clinically, cracks that extend from the dentin to the enamel surface are classified as brown. Those that extend to the dentin are called white cracks. The width of these fissures may range from 0.74 to 5 micrometers.

Due to the importance of preserving dental structures, the objective of this study was to analyze possible injuries to enamel structure when heat is used during in vitro internal dental bleaching.

\section{MATERIAL AND METHODS}

Twenty healthy human mandibular incisors, extracted from adult males and females for various reasons, were selected for this study. The specimens were kept hydrated in saline solution for $72 \mathrm{~h}$. Access cavities were then made with a round \#2 carbide bur (Maillefer, Ballaigues, Switzerland) at high speed and a \#2082 bur (K.G. Sorensen, São Paulo, SP, Brazil). Root canals were prepared with Flexo-File files (Maillefer) to a master apical file size \#40. The canals were filled with gutta-percha cones (Tanari, Manacapuru, AM, Brazil) and N-Rickert cement (Botica ao Veado D'Ouro, São Paulo, SP, Brazil) by the lateral condensation technique.

To obtain initial data, the teeth were examined with a transilluminator (Endo Technic Corporation, Marseille, France) and later photographed with a stereoscopic lens at $12 \mathrm{X}$ magnification (Inalh, Mexico City, Mexico). The specimens were cleaned in a surface cleaner (Metal-Chek R50INF, Porto Alegre, RS, Brazil) to remove any debris. A stain (Metal-Chek VP30Hi, Porto Alegre, RS, Brazil) was applied on the buccal surface of the crown for $5 \mathrm{~min}$ and an indicator agent (Metal-Chek D70Hi) was subsequently used for 5 min to show the presence of any crack. If a crack was present, it would be indicated by a red color. The results enabled the identification of healthy teeth with tufts, with or without communication. The tooth crown was photographed with a stereoscopic lens and classified as: 1) type A crack: fissures present before the test, no dye penetration (non-communicating); type B crack: fissures present before the test, with dye penetration (communicating). The teeth were divided into two groups: group 1 was formed by teeth whose buccal surfaces were healthy in the transillumination and lens exams, confirmed by dye application; group 2 was formed by teeth whose buccal surfaces showed tufts, disclosed by the same methods.

Before dental bleaching, the filled root canals were prepared using hot endodontic pluggers in order to remove $3 \mathrm{~mm}$ of the gutta-percha in the cervical area, filled with zinc phosphate cement.

A $37 \%$ phosphoric acid gel was applied to the pulp chamber and buccal surface for $15 \mathrm{~s}$ in order to increase permeability and enhance the action of the bleaching agent. The acid was removed and the dentin surface dried with water and air spray.

A cotton pellet saturated with $30 \%$ hydrogen peroxide was introduced into the access cavity and the buccal surface was covered with a gauze also saturated with $30 \%$ hydrogen peroxide. A gutta-percha plugger of an adequate diameter (Paiva's plugger) was heated to red-hot in a taper flame and applied to the buccal surface and pulp chamber. This procedure was repeated 3 times at intervals of $48 \mathrm{~h}$.

After the bleaching technique was completed, data was collected in the same manner and classified as: type C: type A cracks emerged when dyed during the test application; type D: cracks increased after the pretest; type E: new cracks could be detected.
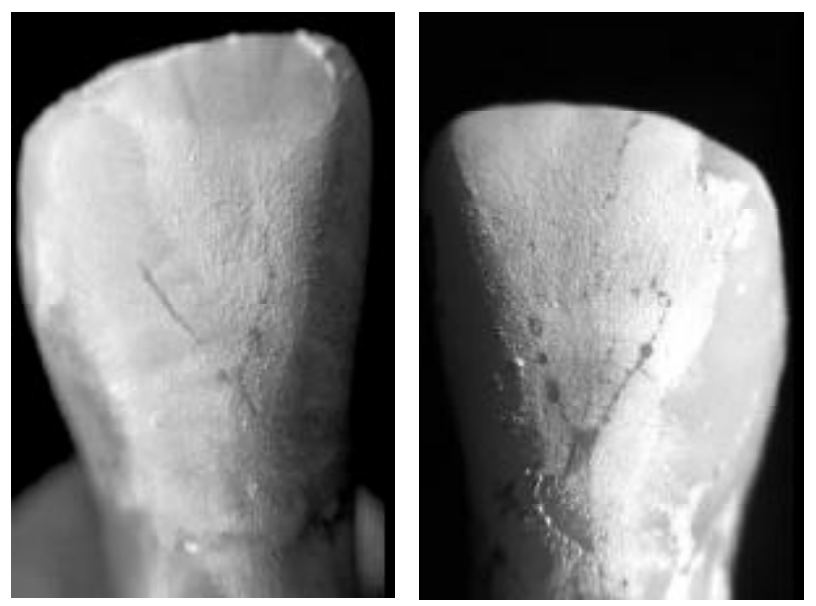

Figure 1. After dental bleaching, a non-communicating tuft showed communication condition $(70 \mathrm{X})$. 
With both sets of data, obtained before and after bleaching, a comparative analysis was performed regarding the presence or absence of enamel cracks, as well as enhancement of pre-existing cracks.

\section{RESULTS}

The teeth of group 1 that were healthy at pretesting had no alteration after bleaching. In group 2 that had tufts on the buccal surfaces at pre-testing, only one tooth with non-communicating tufts showed communication after bleaching (type D - Figure 1). Type C, and E cracks were not detected.

\section{DISCUSSION}

Since the last decade, the color of teeth has gained great importance in esthetics and social acceptance. Thus, dental bleaching has become an alternative to change the color of teeth.

In order to perform this procedure, vital and nonvital techniques use acid and caustic substances that, in contact with heat, raise some doubts related to dental enamel surface injuries (8-11).

Enamel and dentin have different thermo-dynamic behavior. In the presence of cold, enamel contracts faster than dentin, producing stress and causing enamel cracks (7).

Several studies analyzed the effects of thermal tests with cold (cooling gases) on the enamel structure. While Lutz et al. (7) and Bachmann and Lutz (12), using penetrating dyes, reported that carbon dioxide may produce enamel cracks, Barletta and Pesce (8) did not confirm this when they studied the effects of carbon dioxide snow on human dental enamel surface. The literature presents other important studies (9-11) and, as science is dynamic, answers are given at the same time that doubts related to the methods emerge.

There are doubts concerning the precision of silicone impressions to obtain the initial data of preexisting cracks, and concerning the reproduction of human teeth strength in dog teeth. Thus, scanning electron microscopy has been considered an adequate method for this purpose due to its vacuum effects in the analyzing chamber.

In light of these doubts and trying to establish if thermal agents cause injuries to dental structures, this study analyzed the effects of heat in dental bleaching.
The present method was developed from studies that evaluated the use of the fluorescent dye Penetrant P-149 (8), under ultraviolet light that disclosed small diameter cracks, based on the method of Lutz et al. (7). If transillumination and light microscopy are added, it would be possible to precisely classify healthy teeth with the presence of communicating or non-communicating tufts. The use of dyes was based on the research of Lutz et al. (7) and Bachman and Lutz (12). In the present study, dyes were selected based on metallurgy procedures, in which they are used to identify microfissures in metals.

The presence of roughness on the enamel surface, as well as pre-existing internal cracks dated from the eruption phase, could generate some difficulty in interpreting the results at pre- and post-testing. The utilization of transillumination, light microscopy and penetrating dye provides a degree of precision that enables classification according to what is proposed in this methodology.

Results showed that healthy teeth in group 1, when submitted to the bleaching procedure with heat application, showed no alteration, i.e., they remained healthy without the presence of communicating tufts. This can be justified by the great capacity of thermal insulation that enamel and dentin have for both cold and hot $(9,11,13)$.

In teeth from group 2, where there was a presence of non-communicating tufts, only one case became communicating after heat application.

Independent of whether the cracks are of thermal, mechanical or development origin, it is not difficult to classify them. However, the visibility of a pre-existing crack does not allow us to conclude that it has been caused by heat, because the crack origin is unknown. Thermal shock at $-40^{\circ} \mathrm{C}(8)$ evoked no injury in healthy teeth after application of carbon dioxide for $10 \mathrm{~s}$ and no cracks became communicating.

The difficulty in obtaining and interpreting results may be due to the correct classification of pre- and post-testing cracks. Based on Lutz (7) and in light of results at this research, the classification of cracks as types A, B, C and D plus transillumination and light microscopy examinations allowed the interpretation of results to be reliable.

We conclude that in spite of the temperature utilized, enamel and dentin were good thermal insulators; the teeth submitted to heat application in the 
bleaching technique and clasified as healthy did not suffer any type of visible alteration; in the group of teeth with pre-existing, non-communicating cracks, only one tooth became communicating with heat application.

\section{ACKNOWLEDGEMENTS}

This investigation was supported by the Endodontic Teaching and Research Foundation - FEPE Brazil. Dr. R.B. Sydney was the recipient of a CNPq scholarship, 1999-2000.

\section{RESUMO}

Sydney GB, Barletta FB, Sydney RB. Análise in vitro dos efeitos do calor empregado no clareamento sobre o esmalte de dentes humanos. Braz Dent J 2002;13(3):166-169.

Do ponto de vista cosmético, dentes brancos são essenciais para a integração do individuo na sociedade. O clareamento dental é uma das alternativas terapêuticas para alcançar este objetivo. Ao analisarmos as técnicas propostas para o clareamento dental, podemos observar que o calor está freqüentemente envolvido, quer por aplicação direta ou como resultado de um processo químico. $\mathrm{O}$ presente estudo analisou as possíveis injúrias ao esmalte dental quando o calor é empregado nos processos de clareamento. Um método colorimétrico foi empregado e os resultados evidenciaram não haver diferença na estrutura do esmalte dental quando o calor é aplicado. Em apenas um caso, um tufo não comunicante tornou-se comunicante após a aplicação de calor

Unitermos: clareamento dental, tufos de esmalte.

\section{REFERENCES}

1. Baratieri LN. Clareamento Dental. São Paulo: Editora Santos, 1993,176p.

2. Steiner DR, West JD. Bleaching pulpless teeth. In: Goldstein RE Garber DA. eds. Complete Dental Bleaching. Chicago: Quintessense, 1995.

3. Kinomoto Y, Carnes DL, Ebisu S. Cytotoxicity of intracanal bleaching agents on periodontal ligament cells in vitro. J Endodon 2001;27:574-577.

4. Osborn JW, Ten Cate AR. Histologia Dental Avançada. Rio de Janeiro: Quintessence, 1988.231p.

5. Ten Cate AR. Oral Histology: Development, Structure and Function. St. Louis: Mosby, 1985. 234p.

6. Awazawa Y. Measurement of the diameter of crevices in enamel, especially in diameter sizes of enamel crevices as compared with those of enamel lamellae. J Nik Univ Sch Dent 1964;6:41-48.

7. Lutz F, Mormann W, Lutz T. Schmelzsprünge durch die vitalitãtsprüfung mit Kohlesäureschnee. Schweiz Mtsch Zahnheilk 1974;84:709-752.

8. Barletta FB, Pesce HF. Avaliação in vitro dos efeitos na superfície do esmalte dentário humano utilizando-se de bastão de neve carbônica. Rev Odontol USP 1994;8:111-115.

9. Peters DD, Lorton L, Mader CL, Augsburger RA, Ingram TA. Evaluation of the effects of carbon dioxide used as a pulpal test. Part 1. In vitro effect on human enamel. J Endodon 1983,9:219 27.

10. Ingram TA, Peters DD. Evaluation of the effects of carbon dioxide used as a pulpal test. Part 2. In vivo effect on canine enamal and pulp tissues. J Endodon 1983;9:296-303.

11. Peters DD, Mader CL, Donnelly JC. Evaluation of the effects of carbon dioxide used as a pulpal test. Part 3. In vivo effect on human enamel. J Endodon 1986,12:13-20.

12. Bachmann A, Lutz F. Schmealzsprünge durch die sensibilitätsprüfung mit $\mathrm{CO} 2-$ Schnee und Dichlar difluormethaneine vergleicheude in vivo. Untersuchung Schweiz Mtsch Zahnheilk 1976;86:1042-1059.

13. Pesce HF, Barletta FB, Medeiros JMF, Machado MEL. An in vitro evaluation of the effects of three thermal pulp testing on intrapulpal temperature. Rev Odontol UNICID,1995,7:7-11.

Accepted February 6, 2002 